\title{
BIRTHDAY GREETINGS
}

This issue of the revived Psychological Record is an anniversary publication. We have achieved our first birthday. To all who have participated in the realization of this event, to contributor and subscriber alike, we say: "Happy Birthday."

The coming year promises to be an exciting one. Edith Neimark has joined our staff as Book Review Editor. Dave Herman will write and edit a regular featurette, "Perspectives in Psychology." An appropriate subtitle for th is latter department might be "Musings of an Interbehavioral Psychologist." Also, to each issue the editor will contribute a "Quarterly Commentary."

In the present issue of the Psychological Record we feature an article by David Laskowitz, "A Review of the Conceptual Status of Anxiety." This is a bold and critical analysis which commends itself to all thinking psychologists. 